\title{
Systematics of Epyris (Hymenoptera, Bethylidae) from Reserva Biológica de Duas Bocas, Espírito Santo, Brazil
}

\author{
Michelle Silva Corrêa ${ }^{1,2}$ \\ Celso Oliveira Azevedo ${ }^{1}$
}

\begin{abstract}
Epyris longus sp. nov., Epyris paramedius sp. nov., Epyris distinctus sp. nov. and Epyris variatus sp. nov. from Reserva Biológica de Duas Bocas, Espírito Santo, Brazil are described and illustrated. Examination of additional specimens of Epyris crassifemur Evans, 1969 allowed to analyse the intraspecific variation as well as to widen the geographic distribution from Santa Catarina to Espírito Santo. Epyris Westwood, 1832 is recorded for the first time in Espírito Santo.
\end{abstract}

Keywords. Bethylidae; Brazil; Epyris; Hymenoptera; systematics.

\section{INTRODUÇÃO}

Epyris Westwood, 1832 belongs to the subfamily Epyrinae; the genus includes about 60 species from the Neotropical Region (GoRDH \& MócZÁr 1990), of these, 21 were described from Brazil (Amapá, Pará, Mato Grosso, Rio de Janeiro, Paraná and Santa Catarina). Four new species are described herein, all from Espírito Santo State, locality where the genus Epyris is recorded for the first time.

The material examined belongs to the Coleção Entomológica of the Universidade Federal do Espírito Santo, Brazil (UFES). The general terminology follows Evans (1969); for the integument sculpture, HARRIS (1979). The abbreviations used are: LH, length of head; WH, width of head; WF, width of frons; HE, height of eye; OOL, ocello-ocular line; WOT, width of the ocellar triangle; DAO, diameter of anterior ocellus; VOL, vertexocular line; distance from the eye top to vertex crest; LFW, length of forewing.

\section{Epyris longus sp. nov.} (Fig. 1)

Description. Holotype female. Length 6.85 mm; LFW 3.9 $\mathrm{mm}$.

Color. Head and mesosoma black; metasoma castaneous; antennae, palpi, tegulae and legs castaneous; wings subhyaline.

Head (Fig. 1). Mandibles with three teeth, the lower one large and sharpened and the upper one short and rounded. Clypeus angulate. First four antennal segments with ratio of 30:10:11:12; segment III 1.42 times as long as wide; segment XI 1.3 times as long as wide; flagellar pubescence short and subapressed, with erect setae outstanding the short pubescence. Eyes small, scarcely hairy. Frons nearly polished, much punctated. WH 1.22 x LH; WF 0.63 x HE; OOL 1.95 x WOT; frontal angle of ocellar triangle acute; distance from the posterior ocelli to the vertex crest $0.8 \times$ DAO. Vertex slightly convex, corners rounded, temples parallel. VOL $0.77 \times \mathrm{HE}$.

Mesosoma (Fig. 1). Thorax coriaceous and punctated as in frons, except the anterior half of mesoscutum, without punctures. Notauli and parapsidal furrows shallow and inconspicuous, notauli convergent, distant 3.8 times their width behind. Scutellar pits distant each other by 1.28 times its length. Propodeal disc 1.16 times as wide as long; median area weakly carinate; discal carinae extending beyond the half of the disc; sides and declivity of propodeum striate. Mesopleuron with lower fovea closed and with a central pit near the obsolete upper margin. Mid tibiae spinose. Transverse median vein oblique. Metasoma polished.

Type material. Holotype female from BRAZIL, Espírito Santo, Cariacica, Reserva Biológica de Duas Bocas, 25.II.1997, sweeping, C. O. Azevedo col. (UFES).

Remarks. This species belongs to tricostatus group differing from the other species of the group by having a very elongate and much punctate head, and small eyes.

Etymology. The name refers to the elongate head.

1. Departamento de Biologia, Universidade Federal do Espírito Santo. Av. Marechal Campos 1468, Maruípe, 29.040-090 Vitória-ES, Brasil.

2. Bolsista de iniciação científica PIBIC-CNPq/UFES. 


\section{Epyris paramedius sp. nov.}

(Figs. 2-5)

Description. Holotype male. Length $6.5 \mathrm{~mm}$; LFW $4.15 \mathrm{~mm}$.

Color. Body black, apex of metasoma lighter; mandibles, antennae, palpi and tegulae castaneous; legs black, except coxae and tarsi, castaneous; wings subhyaline.

Head (Fig. 2). Mandibles with three apical teeth, the lower one large and sharpened and the upper one short and rounded. Clypeus angulate. First four antennal segments with ratio of 27:12:15:20; segment III 1.5 times as long as wide; segment XI 2.86 times as long as wide; flagellar pubescence short and appressed, with erect setae outstanding the short pubescence. Eyes with sparse hairs. Frons nearly polished, with small punctures. WH 0.94 x LH; WF 1.2 x HE; OOL 1.45 x WOT; frontal angle of ocellar triangle acute; distance from the posterior ocelli to the vertex crest $0.57 \times$ DAO. Vertex slightly convex, with round corners, temples slightly divergent. VOL 0.57 x HE.

Mesosoma (Fig. 2). Thorax coriaceous and punctate as in frons, except the anterior half of mesoscutum, without punctures. Notauli and parapsidal furrows wide and deep behind, inconspicuous anteriorly; notauli convergent, distant 2.2 times their width behind. Scutellar pits distant each other by 1.75 times its length. Propodeal disc 1.97 times as wide as long; median area slightly carinate; median and paramedian carinae complete; lateral discal carinae convergent, extending beyond the anterior half of the disc; sides and declivity of propodeum striate. Mesopleuron with lower fovea closed and with a rounded central pit.

Metasoma polished. Genitalia (Figs. 4-5) with paramere wide, rounded at apex, dorsal margin membranous in the apical half; cuspis with rounded apex, slightly higher than the half of paramere; aedeagus shorter than the apex of cuspis, with two conical apical lobes, base wide and flattened, angled downward laterally, apodeme dilated at base.

Alotype female. Similar to male, except by: length $6.00 \mathrm{~mm}$; LFW $3.75 \mathrm{~mm}$. Color: mandibles, antennae, palpi and tegulae castaneous. Head: first four antennal segments with ratio of 38:12:13:14; segment III 1.15 times as long as wide; segment XI 1.36 times as long as wide; frons weakly coriaceous, with small punctures. WH 0.95 x LH; WF 1.12 x HE; OOL 1.54 x WOT; distance from the posterior ocelli to the vertex crest 0.57 x DAO; VOL 0.57 x HE. Mesosoma: notauli narrow at the anterior fourth, widening backward, distant each other 2.5 times their width behind; scutellar pits long and elliptical, distant each other by 1.63 times its length; propodeal disc 1.54 times as wide as long (Fig. 3).

Type material. Holotype male from BRAZIL, Espírito Santo, Cariacica, Reserva Biológica de Duas Bocas, 12.XI.1996, sweeping, H. S. Sá col. (UFES). Alotype female from BRAZIL, Espírito Santo, Cariacica, Reserva Biológica de Duas Bocas 5.XII.1996, sweeping, C. O. Azevedo col. (UFES). Paratypes: BRAZIL, 18 males, same data as holotype, except 24.IX.1996-16.I.1997, C. O. Azevedo \& H. S. Sá col. (UFES).
Variations. Antennae lighter; punctures of frons deeper; lateral discal carinae of propodeal disc shorter.

Remarks. This species belongs to subspinosus group and runs to Epyris subspinosus Kieffer, 1910 in the key of Evans (1969), but differs by having propodeal disc with well-defined and nearly complete paramedian carinae, lateral discal carinae short, and aedeagus not too deeply emarginated at apex, with the apical lobes sharpened. The sexual dimorphism is limited to the texture of the integument and to the striae of the propodeum.

Etymology. The name refers to the well-defined paramedian carinae of propodeal disc.

\section{Epyris distinctus sp. nov.} (Figs. 6-8)

Description. Holotype male. Length $3.45 \mathrm{~mm}$; LFW $2.6 \mathrm{~mm}$.

Color. Body black; mandibles, antennae, palpi, tegulae and legs castaneous, except coxae black; wings subhyaline.

Head (Fig. 6). Mandibles forming a cutting edge. Clypeus angulate. First four antennal segments with ratio of 16:7:8:12; segment III 1.33 times as long as wide; segment XI 2.2 times as long as wide; flagellar pubescence suberect. Eyes weakly hairy. Frons coriaceous, punctures shallow. WH 0.55 x LH; WF 1.92 x HE; OOL 1.61 x WOT; frontal angle of ocellar triangle acute; distance from the posterior ocelli to the vertex crest $0.4 \times \mathrm{DAO}$. Vertex straight, with round corners, temples parallel. VOL $0.69 \mathrm{x}$ HE.

Mesosoma (Fig. 6). Thorax coriaceous and punctate as in frons, except anterior half of mesoscutum without punctures. Notauli nearly parallel, complete, narrow, slightly widened at posterior half; parapsidal furrows narrow, incomplete anteriorly. Scutellar pits distant each other 2.6 times its length. Propodeal disc 1.26 times as wide as long; median carina complete; sides and declivity of propodeum coriaceous. Mesopleuron with a complete and large foveae occupying all surface of mesopleuron, with an elliptical central pit. Mid tibiae spinose. Transverse median vein oblique.

Metasoma weakly coriaceous. Genitalia (Figs. 7-8) with paramere slightly longer and much wider than basiparamere, dorsal margin widely membranous, with apex subtruncate, inclined; cuspis slightly narrowed at base, slightly higher than the half of paramere; aedeagus as high as the apex of cuspis, with two rounded lobes and emarginated medially at apex, apodeme dilated.

Type material. Holotype male from BRAZIL, Espírito Santo, Cariacica, Reserva Biológica de Duas Bocas, 17.XII.1996, sweeping, H. S. Sá col. (UFES). Paratypes: 6 males, same data of holotype, except 12.XI.1996-25.II.1997, C. O. Azevedo \& H. S. Sá col. (UFES).

Variations. Body longer; legs darker; punctures of frons slightly deeper; pronotum conspicuously hairy.

Remarks. This species belongs to rufipes group and runs to Epyris crassifemur Evans, 1969 in the key of Evans (1969), 

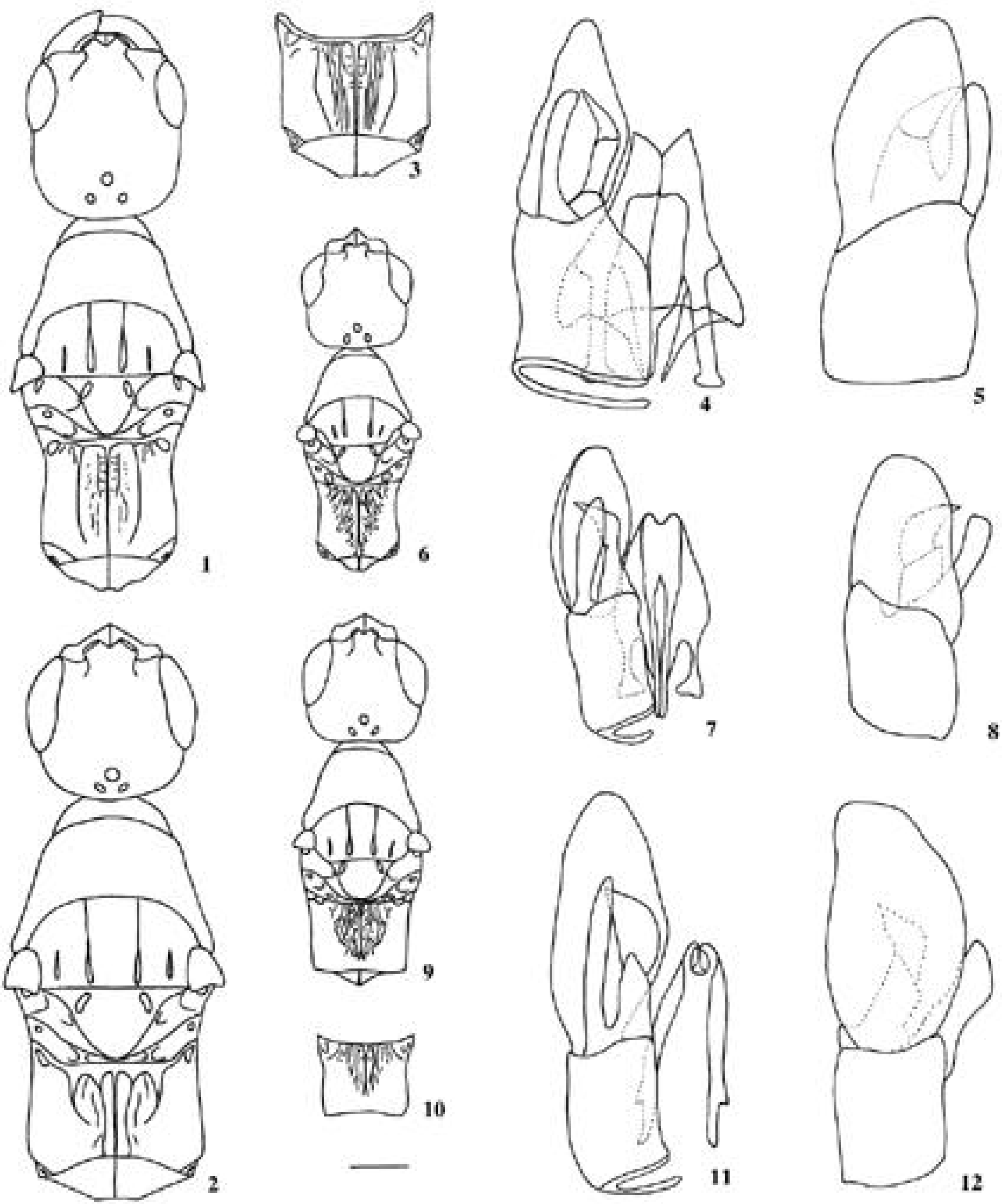

Figs. 1-12. New species of Epyris Westwood. 1, Epyris longus sp. nov., holotype female, head and mesosoma, dorsal; 2-5, Epyris paramedius sp. nov.: 2, paratype male, head and mesosoma, dorsal; $\mathbf{3}$, alotype female, propodeal disc; $\mathbf{4 - 5}$, male genitalia, $\mathbf{4}$, ventral, 5, lateral; 6-8, E. distinctus sp. nov.: 6, holotype male, head and mesosoma, dorsal; 7-8, male genitalia, 7, ventral, 8, lateral; 9-12, Epyris variatus sp. nov.: 9, holotype male, head and mesosoma, dorsal; 10, paratype male, mesosoma; 11-12, male genitalia, 11, ventral, 12, dorsal (scale, body $=417 \mu \mathrm{m}$ and genitalia $=200 \mu \mathrm{m}$ ). 
but Epyris distinctus sp. nov. has the paramere slightly longer than the basiparamere and distinctly higher than the aedeagus, cuspis and digitus about two thirds of the length of paramere and higher than aedeagus, and apodeme with dilated base.

Etymology. The name refers to the paramere distinctly higher than the aedeagus.

\section{Epirys variatus sp. nov.} (Figs. 9-12)

Description. Holotype male. Length $3.95 \mathrm{~mm}$; LFW $2.9 \mathrm{~mm}$.

Color. Body black; mandibles, antennae, palpi, tegulae and legs castaneous, except coxae black; wings subhyaline.

Head (Fig. 9). Mandibles narrow, forming a cutting edge. First four antennal segments with ratio of 16:9:8:6; segment III 1.33 times as long as wide; segment XI 2.2 times as long as wide; flagellar pubescence subappressed, with some erect setae outstanding the short pubescence. Eyes scarcely hairy. Frons nearly polished and little punctated. WH 0.61 x LH; WF $1.9 \times \mathrm{HE}$; OOL $1.5 \times$ WOT; frontal angle of ocellar triangle acute; distance from the posterior ocelli to the vertex crest $0.4 \mathrm{x}$ DAO. Vertex straight, with round corners, temples subparallel. VOL $0.56 \times \mathrm{HE}$.

Mesosoma (Fig. 9). Thorax coriaceous and punctate as in frons, except anterior half of mesoscutum without punctures. Notauli nearly parallel, complete, narrow, slightly widened at posterior half. Parapsidal furrows narrow, absent in the anterior half. Scutellar pits distant each other by 1.78 times its length. Propodeal disc 1.28 times as wide as long; median carina complete. Mesopleuron with a complete and large fovea occupying all surface of mesopleuron, with a rounded central pit.

Metasoma polished. Genitalia (Figs. 11-12) with paramere 1.67 times longer than basiparamere, wide, dorsal margin membranous in the apical half, apex rounded; cuspis 0.7 times as long as paramere; aedeagus lower than cuspis, apex emarginated medially with two rounded lobes, apodeme short.

Type material. Holotype male from BRAZIL, Espírito Santo, Cariacica, Reserva Biológica de Duas Bocas, 26.XII.1996, sweeping, C. O. Azevedo col. (UFES). Paratypes: 90 males, same data of holotype, except 24.IX.1996-25.III.1997, C. O. Azevedo, E. H. Freitas \& H. S. Sá col. (UFES).

Variations. Antennae darker; frons more punctate; median area of propodeal disc with different pattern of striae (Fig. 10), declivity coriaceous; aedeagus as high as cuspis.

Remarks. This species belongs to rufipes group and it is very similar to Epyris perpolitus Evans, 1969, by having long paramere. In E. variatus sp. nov. the paramere is 1.67 times longer than the basiparamere, the cuspis and the digitus are about two third as long as the paramere, and higher than the aedeagus, while in E. perpolitus the paramere is about 2.0 times longer than basiparamere, the cuspis and digitus area about half as long as paramere and as high as aedeagus.

Etymology. The name refers to the great variation of the propodeal disc striae.

\section{Epyris crassifemur Evans, 1969}

This species was known only from Santa Catarina, and now it is recorded for the first time from Espírito Santo. In the males, the antennae may be lighter; the punctures deeper in frons or denser in pronotum; the vertex straight or slightly convex; the corners of the propodeal disc foveolate or not, and the striae of the propodeal disc much variable; parameres slightly higher in relation to those from the type locality.

Material examined. BRAZIL, 5 males, Espírito Santo, Cariacica, Reserva Biológica de Duas Bocas, 04.X.1996-25.III.1997, sweeping, C. O. Azevedo \& H. S. Sá col. (UFES).

Acknowledgments. To Laboratory of Genetics (UFES) by the loan of the camera lucida used to illustrate the genitalia; to Roberto Poltronieri Vieira and Maria Isabel Nascimento (Instituto de Defesa Agropecuária e Florestal, IDAF) by the authorization for sampling in the Reserva Biológica de Duas Bocas.

\section{REFERENCES}

Evans, H. E. 1969. A revision of the genus Epyris in the Americas (Hymenoptera, Bethylidae). Bulletin of the Museum of Comparative Zoology 95(2):181-352.

Gordh, G. \& L. Móczár 1990. A catalog of the world Bethylidae (Hymenoptera, Aculeata). Memoirs of the American Entomological Institute 46:1-364.

Harris, R. A. 1979. A glossary of surface sculpturing. Occasional Papers in Entomology 28:1-31. 